\title{
PERANGKAP VISUAL IKLAN POP UP DI SMARTPHONE
}

\author{
Didit Widiatmoko', Mohamad Tohir ${ }^{2}$ \\ 1,2 Visual Communication Study Program, Telkom University \\ widiatmokodw@gmail.com ${ }^{1}$, mt.fauzy@gmail.com²
}

\begin{abstract}
Abstrak
Kehidupan masyarakat perkotaan seperti tidak terpisahkan dengan penggunaaan smartphone. Perangkat ini memfasilitasi penggunaan berbagai perangkat lunak yang sekarang lebih akrab disebut aplikasi yang berperan memudahkan berbagai urusan mulai dari pemesanan tiket, paket wisata, toko online, hantaran makanan, dan perawatan teknis telepon seperti pembersih file dan antivirus. Aplikasi ini dapat diunduh dari penyedia seperti app gallery atau playstore, baik secara gratis maupun berbayar. Aplikasi yang gratis ketika digunakan tiba-tiba muncul iklan dan pengguna sering terperangkap menekan tombol beli, mainkan game atau install, padahal tidak menyukai iklan ini. Penelitian ini untuk mengetahui bagaimana cara iklan pop up menjebak pengguna secara visual dan respon pengguna terhadap fenomena ini. Menggunakan metode penelitian visual dengan instrumen observasi visual terhadap sampel, wawancara kepada ahli dan kuesioner kepada pengguna. Dari hasil trianggulasi data didapatkan hasil bahwa iklan pop up yang lebih mementingkan exposure dan sebaran cenderung menjebak pengguna smartphone, padahal pengguna tidak ingin membeli produk yang diiklankan
\end{abstract}

Kata kunci : aplikasi, iklan pop up, smartphone

\begin{abstract}
The life of urban society is inseparable from the use of smartphones. This device facilitates the use of various software that are now more familiarly called applications. The applications that play a role in abridging the numerous matters ranging from ticket reservations, tour packages, online shops, food delivery, and telephone technical maintenance such as file cleaners and antivirus. This application can be download from providers such as gallery apps or play store, both free and paid. Applications that are free when used suddenly appear ads and users are often stuck pressing the buy button, play the game, or install, even though they do not like this ad. This research is to find out how to pop up ads visually trap users and user responses to this phenomenon. This research used visual research methods with visual observation instruments on samples, interviews with experts, and questionnaires to users. From the results of the triangulation of data, the results show that pop-up ads that are more concerned with exposure and distribution tend to trap smartphone users, even though users do not want to buy the advertised product.
\end{abstract}

Keywords: application, pop-up ads, smartphone 


\section{PENDAHULUAN}

Pemasaran masa kini tidak bisa hanya mengandalkan media konvensional seperti above the line dan below the line saja, media pemasaran yang harus selalu berinovasi menyesuaikan dengan perkembangan teknologi. Media sosial yang sebelumnya berfungsi sebagai pembentuk eksistensi pribadi di dunia maya, sekarang sudah berubah menjadi media pemasaran. Masa kini masyarakat perkotaan terutama kaum muda menggunakan smartphone. Ditambah lagi dengan produk-produk buatan China dengan teknologi sama dengan buatan Amerika dan Eropa, namun harganya jauh lebih murah. Maka hampir setiap orang dapat memiliki dan mengoperasikan smartphone serta hampir setiap orang terutama anak muda perkotaan memiliki akun media sosial, paling tidak facebook dan instagram. Smartphone dapat memfasilitasi penggunaan berbagai perangkat lunak, sekarang lebih akrab disebut aplikasi, dengan mudah dan gratis dapat diunduh dari Playstore. Aplikasi yang gratis inilah biasanya disisipi iklan dari berbagai produk mulai dari rokok, toko online, biro perjalanan, game, makanan dan minuman. Iklan sisipan ini muncul setiap pengguna membaca berita atau membuka aplikasi gratisan ini. Iklan muncul secara tiba-tiba dan sulit untuk mematikannya sehingga pengguna menjadi terperangkap. Penelitian ini bertujuan untuk mengungkapkan bagaimana perangkap iklan pop up menggunakan unsur-unsur visual seperti layout, perbandingan ukuran, jeda waktu untuk menjebak pengguna smartphone.

Berbeda dengan layar laptop yang berukuran 14 inci, smartphone mempunyai ukuran layar 6 inci sehingga tampilannya lebih padat, dan ada beberapa tombol dan fitur yang tidak muncul pada layar smartphone dibandingkan dengan layar laptop. Pengoperasian layar smartphone menggunakan gestur tangan pada layar sentuh yang lebih responsive dibandingkan dengan keyboard dan mouse pada laptop. Penggunaan gestur tangan ada kelemahannya juga karena penggunaan ibu jari yang terlalu besar untuk tombol kecil sehingga sering salah pencet yang menyebabkan tipo atau salah ketik. Kesalahan pencet ini dapat menekan tombol beli, mainkan atau install, yang berarti pengguna terpaksa membeli produk yang diiklankan.

Iklan yang menggunakan media tradisional telah mengalami pasang surut yang drastis dalam kondisi ekonomi yang tidak menentu sehingga banyak pengiklan menggeser alokasi dananya ke media sosial yang lebih tahan terhadap pengetatan anggaran. Materi iklan harus beradaptasi dengan kecepatan perubahan teknologi, budaya pop dan tren tontonan online, sehingga harus mengembangkan semua komunitas online untuk khalayak sasaran spesifik agar mereka tetap terlibat (Altstiel, Grow \& Jennings, 2020). Bila ditinjau dari sudut tampilan antar muka, maka konsistensi dari tampilan antarmuka pengguna yang terdiri dari Hierarchy : obyek-obyek dalam aplikasi tersusun menurut hirarki kepentingan. Personality : ciri khas aplikasi terlihat pada kesan pertama melihatnya. Layout : susunan elemen-elemen dalam sebuah aplikasi. Type : jenis huruf yang digunakan dalam aplikasi. Color : pemilihan warna yang tepat untuk aplikasi. Imagery: gambar, icon, dan sejenisnya untuk menyampaikan sebuah informasi di dalam aplikasi. Control and Affordances : elemen dari antarmuka pengguna yang dapat digunakan orang untuk berinteraksi dengan sistem melalui sebuah layar. Dalam hal ini kontrol merupakan segala sesuatu yang memfasilitasi pengguna berinteraksi dengan 
data melalui tampilan antarmuka. Baik itu berupa tombol atau ikon (Levinson \& Schlatter, 2013). Cara efektif untuk memunculkan identitas adalah dengan memanfaatkan unsur visual yang merangsang penglihatan (Yusantiar \& Soewardikoen, 2018). Asumsi yang muncul dari kerangka teoretik seperti tampak pada gambar 1 yaitu untuk beradaptasi dengan teknologi Iklan dirancang menggunakan prinsip graphical user interface, ditunjang dengan control and affordance, menjadi iklan pop up yang beredar di smartphone.

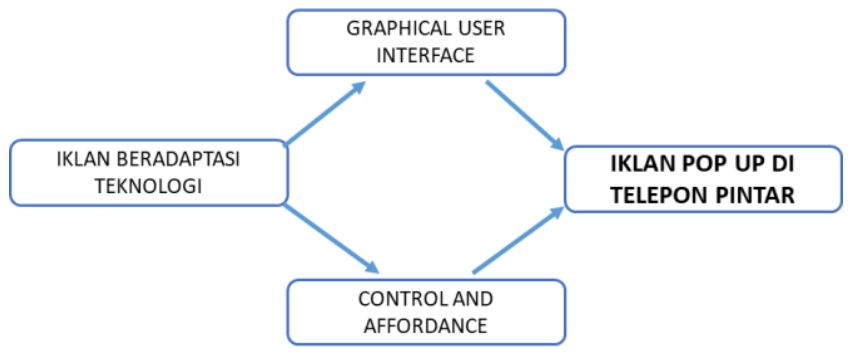

Gambar 1. Kerangka teoretik

[Sumber : Laporan penelitian Dasar Dan Terapan LPPM TelU (Soewardikoen \& Tohir, 2019)]

Posisi penelitian ini, iklan pop up telah di bahas pada beberapa penelitian. Pertama, penelitian dengan topik yang sama telah dilakukan oleh Ayu Saraswati (2014) dengan skripsi berjudul "Analisis Faktor-faktor yang Menyebabkan Iklan Pop Up Dihindari" menggunakan pendekatan studi kasus, research eksploratif bertujuan menemukan problematika baru. Obyek penelitian tersebut adalah iklan di internet secara umum dan sampel yang digunakan adalah 5 (lima) pengguna internet, pengambilan data melalui instrumen wawancara, dan hasil yang didapat adalah mitos buruk dan kehawatiran yang berlebihan sehingga pengguna internet menjadi enggan. Kedua, penelitian berjudul "Pengaruh Iklan Pop up Youtube dan Kualitas Produk Terhadap Minat Beli dengan Kesadaran Merek Sebagai Variable Intervening" (Slamet et al., 2018), oleh Hatmi Pratiwi Cahyani Slamet, N. Rachma dan M. Hufron, ketiganya dari prodi manajemen Fakultas Ekonomi dan Bisnis Universitas Islam Malang. Penelitian ini menggunakan pendekatan kuantitatif yang bertujuan menganalisis dan mengetahui hubungan langsung dan tidak langsung iklan pop up Youtube dan kualitas produk terhadap minat beli dengan kesadaran merek sebagai variabel mediasi atau intervening. Obyek penelitian adalah YouTube dan pengukuran korelasi kualitas produk terhadap minat beli. Dalam penelitian ini sama sekali tidak dibahas tampilan visual atau user interface.

Ketiga, penelitian berjudul "Pengaruh Iklan Pop Up Bukalapak Versi Pahlawan pada Youtube terhadap Sikap Khalayak" (Ammarie \& Nurfebiaraning, 2019), oleh Rivky Husein Ammarie, Silvie Nurfebrianing, ketiganya dari prodi studi IImu Komunikasi Fakultas Komunikasi dan Bisnis Universitas Telkom. Menggunakan pendekatan kuantitatif berdasarkan angka statistik dari jumlah pendapatan yang didapatkan dari unggahan video di Youtube yang dilihat setiap harinya. Mengukur pengaruh dari komponen sikap yaitu kognitif, afektif dan konatif. Dalam penelitian ini lebih menekankan pengukuran statistik, dan tidak ada tampilan visual. Dari tiga penelitian yang telah disebutkan maka penelitian ini membahas trik perangkap terhadap pengguna, dengan pendekatan penelitian visual dengan bukti eksplanasi visual yang secara kasat mata lebih jelas, bukan 
hanya asumsi statistik saja. Untuk validitas dilakukan trianggulasi data dengan pendekatan metode penelitian Desain Komunikasi Visual.

\section{METODE PENELITIAN}

Penelitian ini menggunakan metode penelitian Desain Komunikasi Visual (Soewardikoen, 2019, p. 41) yang menggunakan tiga aspek penelitian visual yaitu aspek karya visual itu sendiri menggunakan istrumen pengamatan visual, pencatatan dan penilaian sesuai teori yang digunakan. Data dari aspek visual dilakukan melalui pengamatan visual pada hasil screenshot pada sampel dari iklan pop up yang muncul pada smartphone dengan operasi android, yaitu pada situs berita, situs kesehatan, dan aplikasi gratis antivirus \& phone cleaner. Data dari aspek pembuat menggunakan instrumen wawancara dilakukan kepada narasumber secara purposive sampling dengan kriteria, yaitu desainer iklan dan praktisi periklanan, serta pakar IT, dan data dari aspek pemirsa mengunakan instrumen kuesioner dilakukan penyebaran kuesioner kepada 100 orang pengguna smartphone dengan rentang usia antara 15 hingga 20 tahun. Hasil pengumpulan data dari tiga aspek penelitian dianalisis trianggulasi menggunakan matriks penarikan kesimpulan (Soewardikoen, 2019, p. 111).

\section{HASIL DAN PEMBAHASAN}

\subsection{Data dari Aspek Karya Visual}

Iklan pop up paling sering muncul ketika pengguna Smartphone ketika membuka situs berita dan menggunakan aplikasi antivirus \& phone cleaner untuk smartphone berbasis android. Berikut diuraikan hasil pengamatan visual berdasarkan graphic user interface serta control and affordance, situs berita (tabel 1), aplikasi antivirus \& phone cleaner (tabel 2 dan tabel 3), selain iklan pop up yang menyerang, ada beberapa iklan yang lebih "sopan" yaitu dengan cara disisipkan pada kolom diantara teks (tabel 4).

Tabel 1. Iklan pop up pada portal berita

[Sumber : Laporan penelitian Dasar Dan Terapan LPPM TelU]

\begin{tabular}{|c|c|}
\hline Tampilan Visual Aplikasi & Hasil Pengamatan \\
\hline 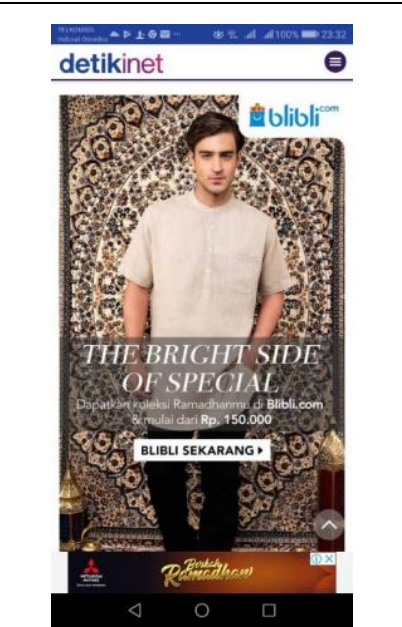 & $\begin{array}{l}\text { Membaca portal berita detikinet, muncul iklan blibli.com, } \\
\text { layout formal menutupi } 85 \% \text { luas layar, huruf menunjang } \\
\text { gambar berupa foto, warna tidak ada yang menonjol, untuk } \\
\text { kontrol tombol yang paling menonjol adalah untuk melakukan } \\
\text { pembelian. Tombol Close berukuran kecil di kanan. }\end{array}$ \\
\hline
\end{tabular}




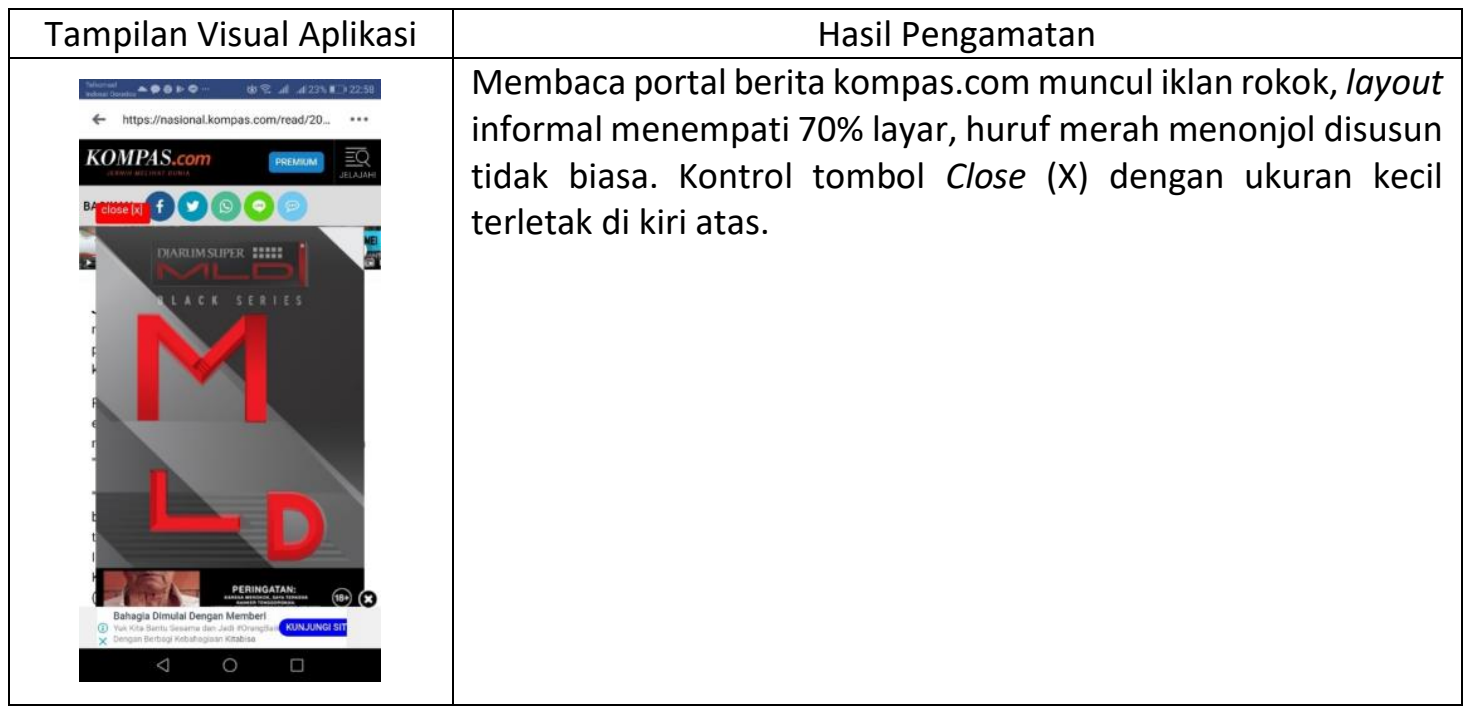

Tampilan iklan menutupi $70 \%$ sampai $85 \%$ luas bidang layar tampilan berita yang seharusnya dibaca. Tombol Close $(\mathrm{X})$ sudah muncul tetapi sangat kecil dibandingkan dengan tombol action (beli) apalagi dibandingkan dengan luas gambar iklan.

Tabel 2. Iklan pop up pada aplikasi virus cleaner

[Sumber : Laporan penelitian Dasar Dan Terapan LPPM TelU]

\begin{tabular}{|c|c|l|}
\hline \multicolumn{2}{|c|}{ Tampilan Visual Aplikasi } & \multicolumn{2}{c|}{ Hasil Pengamatan } \\
\hline saat jeda & setelah jeda & \multicolumn{1}{|c|}{$\begin{array}{l}\text { Ketika mengoperasikan aplikasi Phone Cleaner, } \\
\text { muncul iklan Tik Tok aplikasi video sharing yang } \\
\text { tersebar lebih dari 40 negara di dunia. } \\
\text { Tampilan iklan menutupi 100\% bidang layar. } \\
\text { Yang muncul dominan adalah visualisasi video } \\
\text { menampilkan seorang perempuan dengan } \\
\text { rambut jambul, wajah seronok sedang } \\
\text { berceloteh serta tombol install now yang } \\
\text { dominan, sedangkan tombol Close (X) tidak } \\
\text { langsung muncul, menunggu jeda sekitar } 3 \\
\text { detik. Setelah ikon jeda selesai, tombol Close } \\
\text { (X) muncul, ukuran jauh lebih kecil daripada } \\
\text { tombol install now, dan terletak pada bidang } \\
\text { margin berwarna hitam. }\end{array}$} \\
\hline
\end{tabular}

Menunggu tombol Close $(\mathrm{X})$ muncul, terpaksa pengguna menonton dan mendengarkan perempuan ini berceloteh. Momen beberapa detik inilah yang bisa mengarahkan pengguna ponsel untuk menginstall. Setelah terperangkap pengguna menyesal karena setelah aplikasi terpasang ternyata perempuan seronok seperti pada iklan pop up ternyata jarang ditemui. 
Tabel 3. Iklan pop up pada aplikasi anti virus \& phone cleaner

[Sumber : Laporan penelitian Dasar Dan Terapan LPPM TelU]

\begin{tabular}{|c|c|c|}
\hline \multicolumn{2}{|c|}{ Tampilan Visual Aplikasi } & \multirow{2}{*}{ Hasil Pengamatan } \\
\hline saat jeda & setelah jeda & \\
\hline 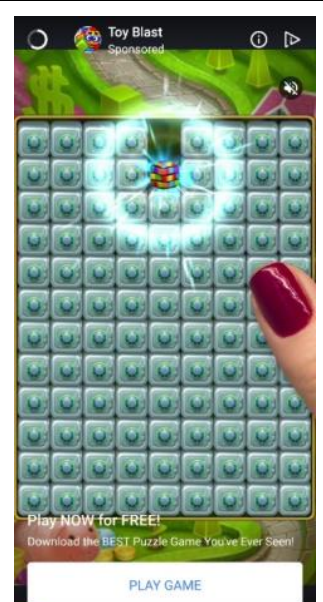 & 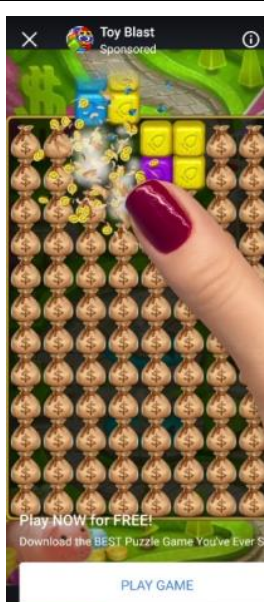 & $\begin{array}{l}\text { Iklan pop up muncul ketika mengoperasikan } \\
\text { aplikasi antivirus \& phone cleaner. Iklan berupa } \\
\text { tampilan game menempati } 100 \% \text { bidang layar. } \\
\text { Yang muncul dominan adalah visualisasi game } \\
\text { dan ibujari yang bergerak, serta tombol Play } \\
\text { Game, sedangkan tombol Close (X) tidak } \\
\text { langsung muncul, menunggu jeda sekitar } 3 \\
\text { detik, menonton cat kuku merah mengkilat } \\
\text { pada ibu jari. Setelah ikon jeda selesai, tombol } \\
\text { Close (X) muncul, ukuran jauh lebih kecil } \\
\text { daripada tombol Play Game }\end{array}$ \\
\hline
\end{tabular}

Game menjadi aktivitas yang digemari, tujuan semula adalah perintang waktu yang mengasyikkan namun perkembangannya dapat menjadikan seseorang lupa waktu dan tidak peduli lingkungan. Sambil menunggu tombol Close $(\mathrm{X})$ muncul pengguna terpaksa menonton ibu jari bercatkuku merah yang lincah, mencenderungkan memencet tombol play game yang berarti menginstall game yang sementara ini play NOW for Free, sebuah perangkap, karena setelah dimainkan langsung berbayar.

Tabel 4. Iklan pada smartphone yang lebih sopan daripada iklan pop up [Sumber : Laporan penelitian Dasar Dan Terapan LPPM TelU]

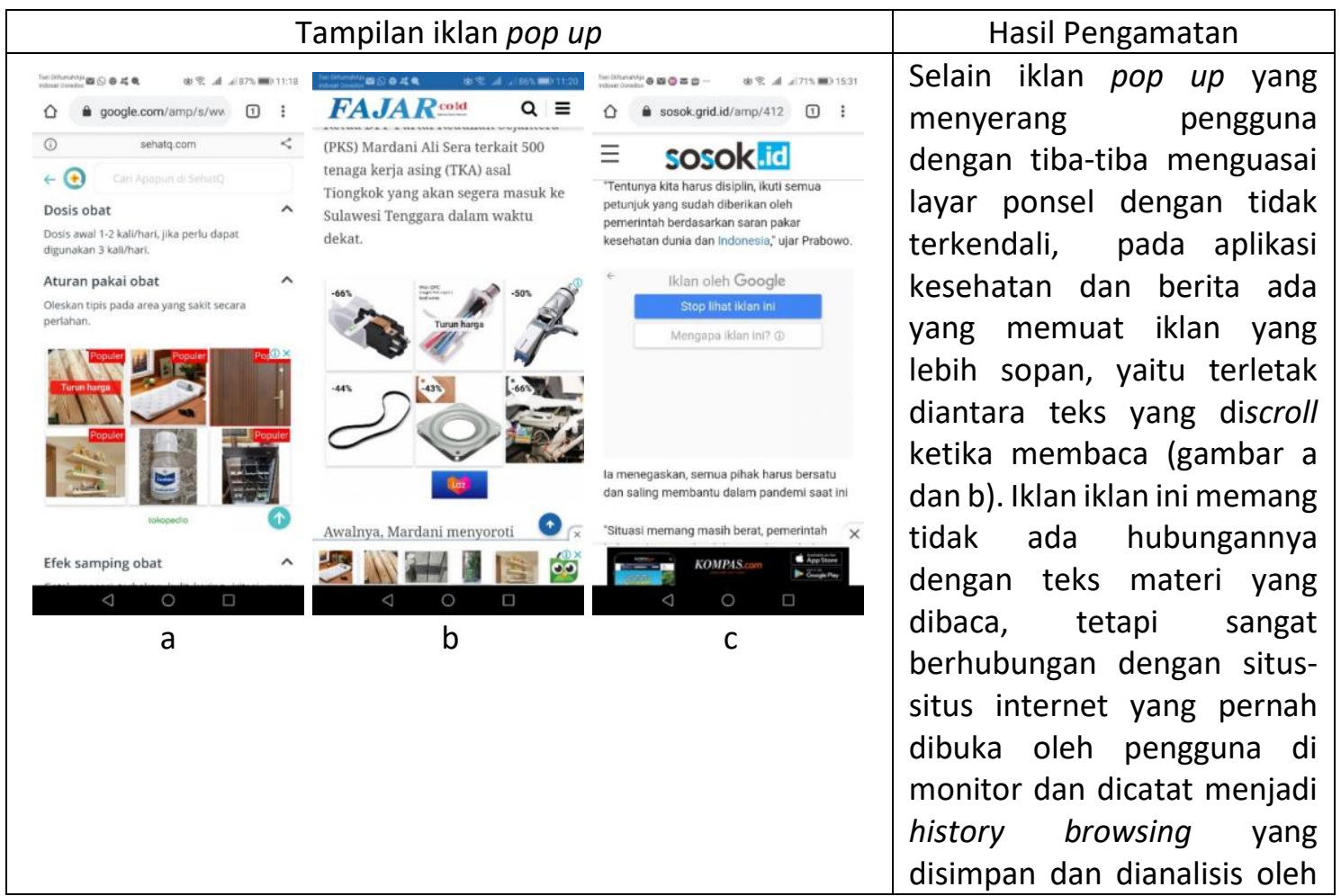




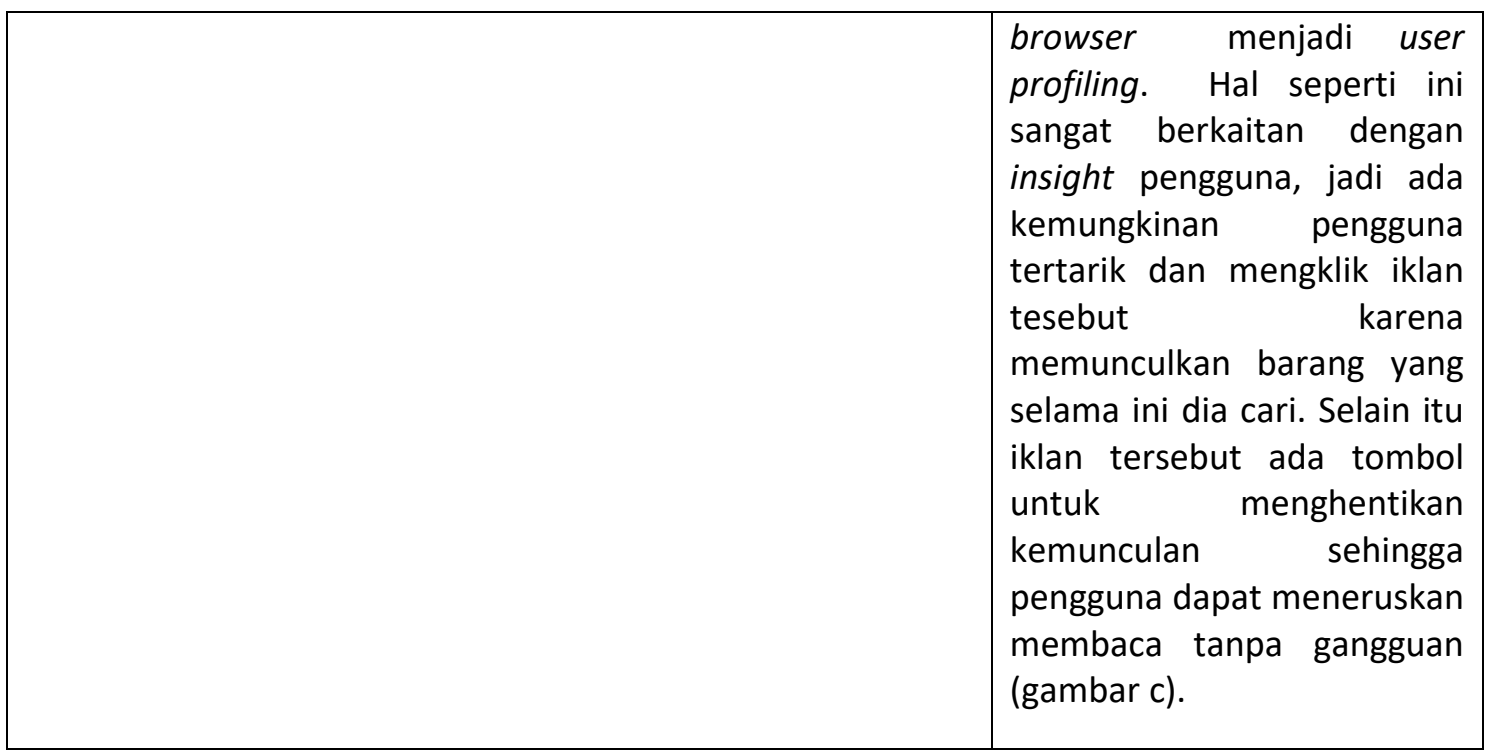

\subsection{Data dari Aspek Pembuat atau Ahli}

Maharani Budi (pakar advertising). Pop up Ads (iklan pop up) yang pertama kali diluncurkan oleh Ethan Zuckerman melalui Tripod.com pada pertengahan era 90-an disinyalir sebagai salah satu model iklan digital yang kontroversial. Kenapa tidak? iklan pop up berkembang menjadi format iklan daring yang paling banyak dipasang oleh pengiklan pada website mereka, sekaligus paling dibenci oleh konsumen. Kemunculan mendadak sebuah jendela iklan di tengah screen dengan visual yang mengganggu seringkali membuat pengunjung website kesal - tidak hanya karena durasinya yang berulang-ulang, beberapa iklan pop up bahkan menampilkan konten iklan dewasa secara acak (parahnya kadang-kadang disertai audio atau animasi tertentu) sehingga pengunjung website akan mencari tombol Close [x] dengan panik, apalagi jika mereka sedang mengakses website tersebut di tempat umum. Padahal Zuckerman mengakui bahwa penemuan itu awalnya dimaksudkan untuk hal yang baik: yakni iklan tersebut dapat menyasar atau menarik perhatian target audiens tertentu tanpa harus dipasang menempel pada body layout dengan memberikan beberapa alternatif produk seperti promosi, pilihan subscribe, dan sebagainya. Dengan demikian, konten iklan pop up tidak perlu diasosiasikan dengan konten Brand di website yang bersangkutan. Namun rupanya tren iklan pop up tumbuh seiring tingkat ketidaknyamanan sebagian besar para pengguna internet. Iklan iklan pop up tidak hanya mendistraksi akses mereka terhadap website yang dituju, namun tidak jarang kontennya dianggap sama sekali tidak sesuai dengan ketertarikan mereka. Selain itu, pengunjung website pun sangat rentan terhadap iklan pop up yang menggunakan teknik Click-bait di bagian teks iklan - seperti Headline yang berani. Tidak heran jika pengguna merasa dijebak oleh pengiklan sehingga mengakibatkan mereka tidak ingin mengunjungi website tersebut untuk kedua kalinya.

Dadang Setiawan (pakar Teknologi Informasi). Sering mendapatkan iklan pop up ketika membuka browser ke beberapa alamat web tertentu. Biasanya ketika mengakses alamat-alamat streaming dan situs berita online. Iklan pop up tersebut dapat muncul pada saat mulai membuka alamat tersebut, tapi kadang dapat juga muncul pada saat membuka salah satu menunya. Kemunculan iklan pop up mengganggu karena dapat 
mengalihkan fokus dari tujuan awal, selain itu penawaran yang diberikan mayoritas tidak sesuai dengan minat, sehingga semakin tidak berminat untuk membuka iklan pop up tersebut. Sebetulnya iklan pop up dapat lebih efektif jika kemunculannya dibuat tidak terlalu agresif. Misalnya, muncul setiap dua atau tiga kali akses, dengan demikian, rasa terganggu akibat iklan yang selalu muncul akan berkurang, dan memperbesar kemungkinan seseorang untuk memperhatikan konten dari iklan tersebut. Cara kedua dan yang sudah lebih terbukti adalah dengan menggunakan data analytics, dimana yang ditawarkan kepada orang yang membuka situs adalah hal-hal yang cukup sesuai dengan minat dan hobi orang tersebut.

Jiwa Utama (desainer dan praktisi Advertising). Iklan pop up sudah menjadi bagian dari dunia digital pada saat ini. Bagi para konsumen yang sering menggunakan media digital seperti penggunaan internet dan media sosial pada khususnya, dipastikan sudah tidak asing lagi dengan kemunculan iklan yang tiba-tiba, terutama ketika membuka situs tertentu atau bahkan aplikasi berita dan media sosial. Kemunculan iklan yang tidak diduga sering kali membuat para pengguna internet merasa kesal karena dianggap mengganggu ketika menggunakan internet pada saat membuka website tertentu. Ada beberapa kasus tertentu yaitu ketika gambar atau video yang muncul memang tidak bisa menarik perhatian sama sekali, kemungkinan besar iklan tersebut akan langsung di lewati oleh para user internet pada platform media apapun. Namun ketika ternyata visual atau video yang ditampilkan sesuai dengan interest dari user internet yang melihatnya, biasanya akan dilihat atau bahkan hingga sampai mengikuti instruksi yang terdapat pada iklan pop up tersebut. Dapat disimpulkan, ketika iklan pop up tujuannya tidak terarah dalam hal ini hanya mementingkan exposure yang "hanya sekedar tersebar" akan terbentur dengan resiko para user tidak akan melihat dan bahkan langsung menutup iklan pop up tersebut. Sementara jika iklan pop up tersebut memang dirancang dengan mempertimbangkan interest dari calon user yang akan dikirim, tentunya akan membuat kemungkinan dari iklan pop up tersebut untuk dilihat bahkan diikuti hingga ke media yang terintegrasi akan semakin besar. Faktor interest tersebut tentu saja mencakup seperti apa daya tarik visual yang digunakan berdasarkan strategi kreatif yang telah ditentukan untuk kemudian diaplikasikan pada iklan pop up tersebut. Insight konsumen sangat penting dalam hal ini.

Iklan pop up tumbuh seiring tingkat ketidaknyamanan sebagian besar para pengguna internet. Iklan pop up tidak hanya mendistraksi akses terhadap website yang dituju, juga kontennya tidak sesuai dengan ketertarikan pemirsa. Jika tujuannya tidak terarah dan hanya mementingkan sebaran exposure maka pemirsa langsung menutupnya. Iklan pop up dapat lebih efektif jika kemunculannya tidak sering dan yang ditawarkan adalah halhal yang sesuai dengan minat pemirsa. Yang perlu diperhatikan adalah faktor interest yang mencakup insight dan daya tarik visual. 


\subsection{Data Dari Aspek Pemirsa}

Tabel 5. Data hasil kuesioner yang disebarkan melalui google doc $(n=100)$ [Sumber : Laporan penelitian Dasar Dan Terapan LPPM TelU]

\begin{tabular}{|c|c|c|c|c|}
\hline No & Kriteria Pertanyaan & Grafik Jawaban & & Pembahasan \\
\hline 1 & Usia Pemirsa & & $\begin{array}{l}15-25 \\
-26-45 \\
->46\end{array}$ & $\begin{array}{l}\text { Sebagian besar } \\
\text { pengguna } \\
\text { smartphone usia } 15 \\
\text { - } 25 \text { tahun }\end{array}$ \\
\hline 2 & $\begin{array}{l}\text { Terjebak oleh iklan } \\
\text { Pop up }\end{array}$ & & $\begin{array}{l}\text { Ya } \\
\text { Tidak }\end{array}$ & $\begin{array}{l}\text { Semua terjebak } \\
\text { oleh iklan pop up }\end{array}$ \\
\hline 3 & $\begin{array}{l}\text { Terganggu oleh } \\
\text { iklan Pop up }\end{array}$ & & $\begin{array}{l}\text { Ya } \\
\text { Tidak }\end{array}$ & $\begin{array}{l}\text { Sebagian besar } \\
\text { terganggu oleh } \\
\text { iklan pop up }\end{array}$ \\
\hline 4 & $\begin{array}{l}\text { Menemukan } \\
\text { tombol Close (X) }\end{array}$ & & $\begin{array}{l}\text { Ya } \\
\text { Tidak }\end{array}$ & $\begin{array}{l}\text { Lebih banyak yang } \\
\text { tidak menemukan } \\
\text { tombol Close }\end{array}$ \\
\hline 5 & $\begin{array}{l}\text { Aplikasi yang } \\
\text { membawa iklan } \\
\text { pop up }\end{array}$ & & $\begin{array}{l}\text { Berita } \\
\text { Aplikasi } \\
\text { Medsos } \\
\text { Lainnya }\end{array}$ & $\begin{array}{l}\text { Sebagian besar } \\
\text { ketika membuka } \\
\text { situs berita }\end{array}$ \\
\hline
\end{tabular}




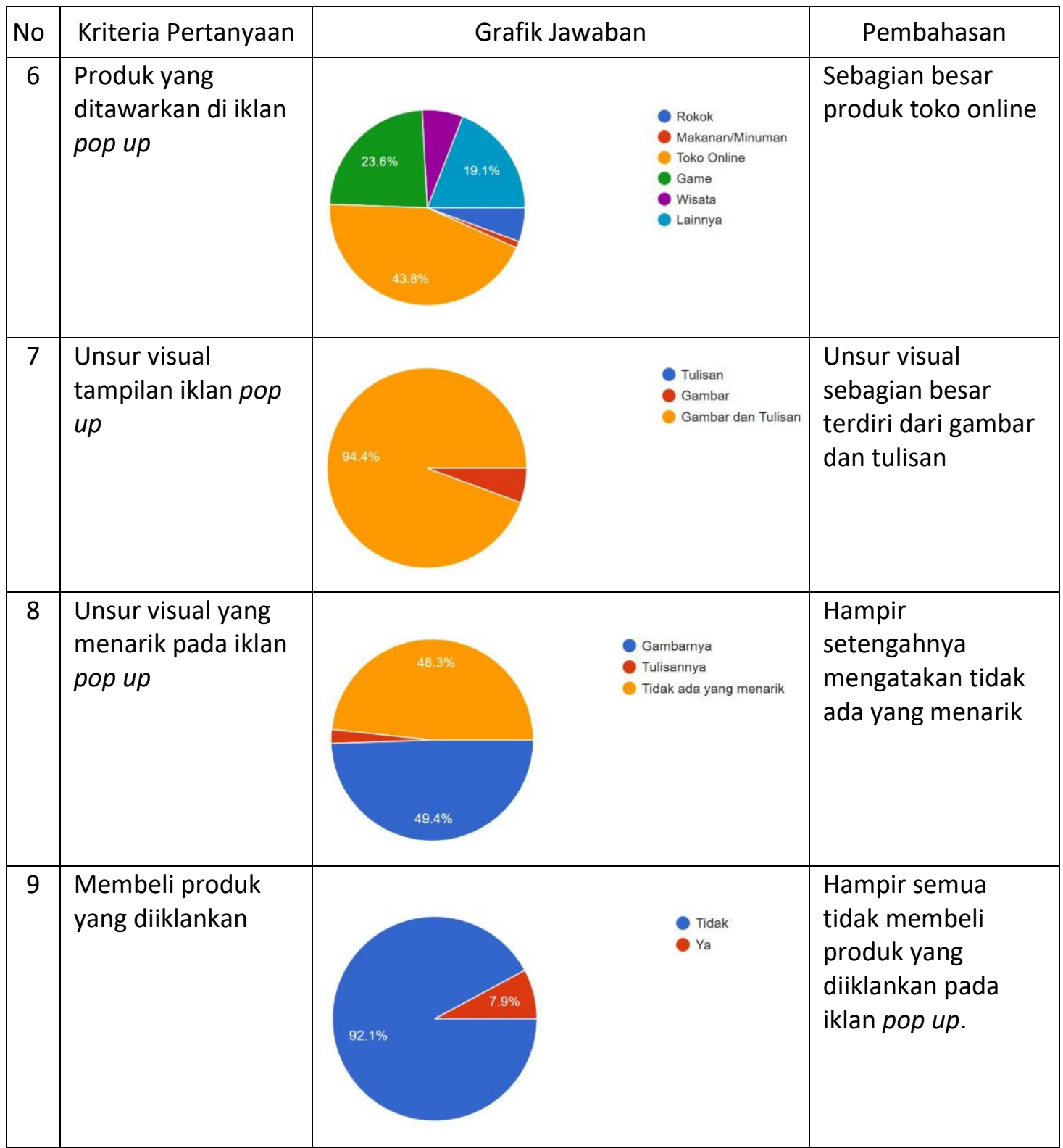

Rangkuman hasil kuesioner, sebagian besar pengguna smartphone berusia $15-25$ tahun. Hampir semua pernah terperangkap oleh iklan pop up. Lebih banyak pengguna sulit menemukan tombol Close. Sebagian besar terkena iklan pop up ketika membuka situs berita, baru kemudian aplikasi. Dominan pemasang iklan pop up di smartphone adalah toko online, baru kemudian game. Iklan pop up terdiri dari gambar dan tulisan. Hampir semua pengguna berpendapat iklan pop up tidak ada yang menarik. Hampir semua pengguna tidak membeli produk yang menggunakan iklan pop up. 
Tabel 6. Matriks trianggulasi data dan penarikan kesimpulan

[Sumber : Laporan penelitian Dasar Dan Terapan LPPM TelU]

\begin{tabular}{|l|l|}
\hline $\begin{array}{l}\text { Rangkuman hasil } \\
\text { pengamatan visual }\end{array}$ & $\begin{array}{l}\text { Iklan pop up menutupi situs yang dituju, tombol (X) ada } \\
\text { jeda tidak langsung muncul dan proporsi minim, yang } \\
\text { dominan muncul adalah gambar atau video yang berusaha } \\
\text { mempersuasi dan tombol besar untuk membeli atau } \\
\text { menginstall. Selain iklan pop up yang menyerang dan } \\
\text { cenderung tidak disukai, ada iklan yang munculnya lebih } \\
\text { sopan dan lebih sesuai dengan insight pengguna. }\end{array}$ \\
\hline $\begin{array}{l}\text { Rangkuman hasil } \\
\text { wawancara kepada } \\
\text { ahli periklanan dan IT }\end{array}$ & $\begin{array}{l}\text { Iklan pop uptumbuh seiring tingkat ketidaknyamanan } \\
\text { sebagian besar para pengguna internet. Iklan pop up tidak } \\
\text { hanya mendistraksi akses terhadap website yang dituju, } \\
\text { juga kontennya tidak sesuai dengan ketertarikan pemirsa. } \\
\text { Jika tujuannya tidak terarah dan hanya mementingkan } \\
\text { sebaran exposure maka pemirsa langsung menutupnya. } \\
\text { Iklan pop up dapat lebih efektif jika kemunculannya tidak } \\
\text { sering dan yang ditawarkan adalah hal-hal yang sesuai } \\
\text { dengan minat pemirsa. Yang perlu diperhatikan adalah } \\
\text { faktor interest yang mencakup insight dan daya tarik } \\
\text { visual. }\end{array}$ \\
\hline Rangkuman hasil \\
kuesioner & $\begin{array}{l}\text { 95\% pernah terperangkap oleh iklan pop up, pengguna } \\
\text { sulit menemukan tombol Close. Dominan terkena iklan } \\
\text { pop up ketika membuka situs berita, baru kemudian } \\
\text { aplikasi. 92,1\% tidak membeli produk iklan pop up. }\end{array}$ \\
\hline
\end{tabular}

\section{KESIMPULAN}

Peran smartphone sebagai sarana penyebaran maka iklan harus beradaptasi dengan kecepatan perubahan teknologi, budaya pop dan tren sudah memenuhi persyaratan ini, bahwa iklan barang, produk dan hiburan sudah menggunakan smartphone sebagai sarana yang mutakhir. Gambar dalam iklan memiliki fungsi menarik dan mempersuasi karena bahasa gambar lebih cepat tersampaikan daripada bahasa tulisan. Selain gambar juga tata letak dan ukuran unsur visual seperti tombol bertulisan. Orang cenderung memencet tombol yang berukuran besar yang berdekatan dengan gambar, padahal tombol itu adalah action untuk membeli, sedangkan tombol untuk menghindari atau menolak berukuran kecil berada di pinggiran frame halaman, itupun tidak langsung muncul karena jeda beberapa detik, sehingga kecenderungannya kembali ke tombol action beli yang berukuran besar.

Tampilan iklan pop up secara Graphical User Interface (GUI) media virtual yang memudahkan dalam mencari informasi bagi pengguna, karena menu sudah tertera dengan tampilan sebuah ikon yang dapat digunakan sebagai objek interaksi yang sesuai dengan fungsinya, sudah memenuhi persyaratan ini, namun secara Affordance and Visibility pada iklan pop up tombol menolak atau Close tidak terlihat jelas, justru yang jelas dan cenderung memaksa adalah menu beli atau install, inilah yang menjadi 
perangkap bagi pengguna. Tetapi lebih signifikan dari semua itu bahwa pengguna tidak membeli produk yang diiklankan. Iklan pop up dapat lebih efektif jika kemunculannya lebih teratur, tidak memaksa serta yang ditawarkan adalah hal-hal yang sesuai dengan minat, faktor interest yang mencakup insight pengguna.

\section{UCAPAN TERIMAKASIH}

Terimakasih kepada Bapak Dadang Setiawan, pakar Information Technology, yang telah mengulas tentang perilaku pengguna melalui user experience. Terimakasih kepada ibu Maharani, pakar Periklanan, yang telah menguraikan bagaimana unsur-usur visual iklan pop up dapat menjebak pengguna ponsel, serta terimakasih kepada bapak Jiwa Utama, praktisi Periklanan, yang menguraikan bahwa pengiklan lebih mementingkan frekuensi exposure daripada mempertimbangkan insight kahalayak sasaran. Data dari para narasumber ini dapat lebih menjelaskan bagaimana perangkap iklan pop up di smartphone.

\section{DAFTAR PUSTAKA}

Altstiel, T., Grow, J., \& Jennings, M. (2020). Advertising creative : Strategy, Copy, Design (4th ed.). SAGE Publications.

Ammarie, R. H., \& Nurfebiaraning, S. (2019). Pengaruh Iklan Pop upBukalapak Versi Pahlawan Pada Youtube Terhadap Sikap Khalayak. Jurnal Manajemen Komunikasi, 2(2), 78.

Ayu Saraswati. (2014). Analisis Faktor-Faktor Yang Menyebabkan Iklan Pop Up dihindari. Universitas Diponegoro, Semarang.

Joseph, J. LaViola. 2011. 3D User Interface. New York: Addison-Wesley Proffesional.

Levinson, D., \& Schlatter, T. (2013). Visual usability: principles and practices for designing digital applications. Morgan Kaufmann imprint of Elsevier.

Rose, G. (2001). Visual Methodologies, An Introduction to the Interpretation of Visual Materials, London : Sage Publications.

Satzinger, J.W., Jackson, R.B., \& Burd, S.D. (2012). System Analysis and Design in A Changing World. Boston: Course Technology.

Slamet, H., Rachma, N., \& Hufron, M. (2018). Pengaruh iklan Pop upYoutube dan Kualitas Produk terhadap Minat Beli dengan Kesadaran Merek sebagai Variabel Intervening. E-Jurnal Riset Manajemen, 82-94.

Soewardikoen, D. W. (2015). Visualisasi Iklan Indonesia Era 1950-1957. Edisi 2. Yogyakarta: Calpulis.

Soewardikoen, D. W. (2019). Metodologi Penelitian Visual dari Seminar ke Tugas Akhir. In Yogyakarta: PT. Kanisius. PT Kanisius.

Soewardikoen, D. W., \& Tohir, M. (2019). Soewardikoen, D.W., Tohir M., 2019, Iklan Pop up di Telpon Pintar, Bandung : Laporan Penelitian Dasar dan Terapan Batch 2 tahun 2019, PPM Universitas Telkom.

van Leeuwen, T., \& Kress, G. (2006). Reading Images: The Grammar of Visual Design. London: Routledge.

Yusantiar, R., \& Soewardikoen, D. W. (2018). Perancangan Identitas Visual untuk Promosi Pariwisata Kabupaten Rembang. ANDHARUPA: Jurnal Desain Komunikasi Visual \& Multimedia, 4(02), 207-220. 